[Original]

\title{
Study of Atypical Femoral Fracture Cases Coupled in a Multicenter Study
}

\author{
Yukichi Zenke ${ }^{1 *}$, Satoshi Ikeda ${ }^{2}$, Fumio Fukuda ${ }^{3}$, Masahiro TAnaka ${ }^{4}$, Hidetoshi TanakA ${ }^{2}$, Fumitaka Hirano ${ }^{5}$ \\ and Akinori SAKAI ${ }^{6}$ \\ ${ }^{1}$ Department of Orthopaedic Surgery, University Hospital of Occupational and Environmental Health, Japan. \\ Yahatanishi-ku Kitakyushu 807-8555, Japan \\ 2 Department of Orthopaedic Surgery, Kenai Memorial Hospital. Ongagun, Fukuoka 811-4313, Japan \\ ${ }^{3}$ Department of Orthopaedic Surgery, Kitakyushu General Hospital. Kokurakita-ku Kitakyushu, Fukuoka 802-8517, \\ Japan \\ ${ }^{4}$ Department of Orthopaedic Surgery, Mazda Hospital. Akigun, Hiroshima 735-0017, Japan \\ ${ }_{5}^{5}$ Department of Orthopaedic Surgery, Kyushu Rosai Hospital Moji Medical Center. Moji-ku Kitakyushu, Fukuoka \\ 801-0853, Japan \\ ${ }^{6}$ Department of Orthopaedic Surgery, School of Medicine, University of Occupational and Environmental Health, Japan. \\ Yahatanishi-ku, Kitakyushu 807-8555, Japan
}

\begin{abstract}
There are several causes of atypical femoral fractures (AFF) in elderly Japanese patients, including longterm bisphosphonate (BP) use or bowed femoral shaft stress fractures, but the available sample size for examining AFF etiology in a single institution is limited. The purpose of this study was to categorize the characteristics of AFF by analyzing the data compiled on patients treated at our hospital and at affiliated institutes. This multicenter, retrospective, observational study included $34 \mathrm{AFF}$ cases (bilateral AFF 10) in one male and 23 female patients (age range 30-90 years, mean age 73.0 years). Evaluation measures included the presence/absence of BP use, duration of BP use, history of other drug use, presence/absence of comorbidities, fracture site, presence/absence of femoral lateral bowing, bone biopsy parameters, and time to bone union. Nineteen patients were prescribed BP for osteoporosis (duration range 4-10 years, mean duration 6.1 years). Subtrochanteric and femoral shaft fractures were seen in 16 and 18 cases, respectively (complete fractures 22, incomplete fractures 12). Femoral lateral bowing $(n=16)$ occurred with femoral shaft fractures. Mean time to bone union was 9.0 months (complete fractures 11.3 months, incomplete fractures 3.7 months). AFF could be substantially caused by three factors: BP use, drugs other than BP/ comorbidity, and femoral lateral bowing. Twenty four patients were classified as having BP-related-type $(n=2)$, drug/comorbidity-type $(n=3)$, lateral bowing-type $(n=2)$, or mixed-type $(n=17)$ AFF. AFF etiology cannot be explained by a single cause; thus, a multifactorial etiology, including poor bone quality due to mutual interactions and mechanical stress, seems to be responsible for the occurrence of AFF.
\end{abstract}

Level of evidence: IV diagnostic

Keywords : atypical femoral fracture, multicenter study, bisphosphonate, lateral bowing, multifactorial.

(Received June 9, 2016, accepted August 8, 2016)

\footnotetext{
*Corresponding Author: Yukichi ZenKe, Department of Orthopaedic Surgery, University Hospital of Occupational and Environmental Health, Japan. Yahatanishi-ku Kitakyushu 807-8555, Japan, Tel: +81-93-691-7444, Fax: +81-93-692-0184, E-mail: ukichi.drz@gmail.com
} 


\section{Introduction}

Atypical femoral fracture (AFF) is considered to be a complication associated with the long-term use of bisphosphonates (BPs)[1]. In recent years, the theory of "severely suppressed bone turnover (SSBT)," in which the suppression of bone turnover adversely affects bone material properties and strength (proposed by Odvina et $a l$ ), has received attention as the major cause of AFF[1]. The SSBT theory has increasingly been reported in relation to the etiology of AFF, although the pathophysiology of AFF is yet to be understood.

Stress fracture of the bowed femoral shaft is another cause of AFF in elderly Japanese and Taiwanese patients $[2,3]$. Mechanical analysis using a computed tomography (CT)-based finite element method has revealed that significant tensile stress on the anterolateral surface of the femur due to a bowing deformity could induce AFFs [4].

A possible reason why the etiology of AFF is not fully understood is that the sample size available to examine the etiology of AFF in a single institution is limited. The present multicenter study aimed to categorize the characteristics of AFF by analyzing the data compiled on patients treated at our hospital and at affiliated institutions.

\section{Subjects and Methods}

This study was approved by the institutional review board at each participating study site. The purposes and procedures of this study were explained to all participants, and their informed consent was obtained for participation in the study.

\section{Study design}

This multicenter, retrospective, observational study was conducted in patients with AFF at 9 institutions in Japan. Patients were enrolled in the study between October 2010 and April 2015. A questionnaire form was used for data collection.

The study included 34 cases of AFF (including 10 cases of bilateral AFF) in 24 patients who met the criteria for AFF as defined by the revised American Society for Bone and Mineral Research (ASBMR) Taskforce proposed by Shane E. [5, 6]. All five ma- jor criteria were required for the definition of atypical fracture. All the fractures were associated with lowenergy trauma, such as a fall from standing height or less, and were located in the femoral shaft below the lesser trochanter and above the supra condylar flare. We excluded pathological fractures and those arising from metabolic disorders apart from osteoporosis, and patients with any implant in the femur prior to fracture. In one male and 23 female patients (age range 30-90 years, mean age 73.0 years) there were 13 right-sided and 21 left-sided fractures. All the patients could be observed (follow up rate was $100 \%$ ).

\section{Study assessment}

The parameters evaluated were height/weight, presence/absence of BP use, duration of BP use, history of active Vitamin D use, history of other relevant drug use, comorbidities, bone mineral density (BMD; the lumbar spine/proximal femur), bone turnover markers [tartrate-resistant acid phosphatase 5b (TRACP$5 b)$ and intact amino-terminal propeptide of type 1 procollagen (P1NP)], blood test data [calcium (Ca) phosphorus $(\mathrm{P})$, serum homocysteine, undercarboxylated-osteocalcin (uc-OC), and pentosidine], fracture sites (subtrochanteric region/femoral shaft), presence/ absence of lateral bowing of the femur, presence/absence of prodromal symptoms, duration of prodromal symptoms, bone biopsy parameters, presence/absence of low-intensity pulsed ultrasound (LIPUS) therapy after sustaining bone fractures, presence/absence of teriparatide use, and time to bone union.

The lateral bowing angle of the femur was calculated according to the method proposed by Fujimaki et al., [7] (Fig. 1), and femoral lateral bowing was defined as when the lateral bowing ratio exceeded $60 \%$.

A bone biopsy was also performed at a site just below the femoral trochanteric entry point of the nail. A histomorphometric analysis of the biopsy specimen revealed the bone texture and bone turn over markers.

\section{Results}

1. Bisphosphonates, other drugs, comorbidities and fracture location

The results of the main outcome measures are shown in Table 1. BP preparations were used in 19 of 24 pa- 


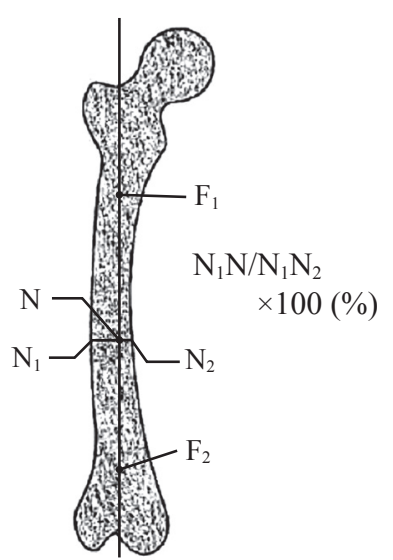

Fig. 1. Method of lateral bowing measurement by Fujimaki. (Reproduced modification from ref. Fujimaki Y. et al (2002): The radiological examination for the lateral bowing deformity of femur. Kansetugeka 21: 1145, Fig.1. with permission of the Medical View co.)

tients (79.2\%), and the mean duration of BP treatment (alendronate in 15 patients and risedronate in 4 patients) was 6.1 years (4-10 years). Active Vitamin D was administered in 10 of 24 patients $(41.7 \%)$, with a mean duration of 3.8 years (1-7 years). Both BP and active Vitamin D were used in 9 of 24 patients (37.5\%). Other drugs used were steroids in 7 patients, proton-pump inhibitors (PPI) in 5 patients, and thiazolidine (TZD) in 1 patient. The comorbidities in this study population were diabetes mellitus (DM) in 3 patients, systemic lupus erythematosus (SLE) in 3 patients, chronic kidney disease (CKD) in 3 patients, and rheumatoid arthritis (RA) in 1 patient. Thirty-four cases of AFF were classified as subtrochanteric fracture $(n=16)$ or femoral shaft fracture $(n=18)$ according to the fracture site. There were 12 incomplete fractures in the subtrochanteric region $(n=6)$ and in the femoral shaft $(n=6)$.

2. Bone mineral density, bone turnover markers, and blood test data

The results of bone assessment are shown in Table 2. Lumbar spine or proximal femur BMD was not reduced when the calculations were based on the youngadult mean BMD and mean BMD. The mean values of other bone turnover parameters and blood test variables were all within the normal range, except for the serum homocysteine level.
Table 2. Bone assessments and blood biochemical parameters

\begin{tabular}{lrrr}
\hline Characteristic & \multicolumn{2}{c}{ Average \pm SD } & (Range) \\
\hline YAM (L2-4) $(\%)$ & $80.0 \pm$ & 18.4 & $(58-115)$ \\
BMD $(\mathrm{L} 2-4)\left(\mathrm{g} / \mathrm{cm}^{2}\right)$ & $0.83 \pm$ & 0.2 & $(0.6-1.16)$ \\
YAM (Femoral neck) $(\%)$ & $73.5 \pm$ & 14.0 & $(51-98)$ \\
BMD (Femoral neck) $\left(\mathrm{g} / \mathrm{cm}^{2}\right)$ & $0.60 \pm$ & 0.1 & $(0.4-0.77)$ \\
TRACP-5b (mU/d) & $341.1 \pm 188.3$ & $(175-745)$ \\
Intact P1NP $(\mu \mathrm{g} / \mathrm{l})$ & $39.3 \pm$ & 30.7 & $(6.4-110)$ \\
Ca (mg/dl) & $9.2 \pm$ & 0.9 & $(8.7-10.4)$ \\
P (mg/dl) & $3.3 \pm$ & 0.7 & $(2.6-4.2)$ \\
Serum homocysteine* $(\mathrm{mg} / \mathrm{l})$ & $14.6 \pm$ & 10.6 & $(5.7-36.1)$ \\
ucOC (ng/ml) & $3.2 \pm$ & 6.4 & $(0.39-17.0)$ \\
Pentosidine $(\mu \mathrm{g} / \mathrm{ml})$ & $0.06 \pm$ & 0.05 & $(0.02-0.08)$ \\
\hline
\end{tabular}

*: Normal level; $<6.3 \mu \mathrm{mol} / l$, YAM: young adult mean, BMD: bone mineral density, TRACP-5b: tartrate-resistant acid phosphatase 5b, P1NP: amino-terminal propeptide of type 1 procollagen, $\mathrm{Ca}$ : calcium, P: phosphorus, ucOC: undercarboxylatedosteocalcin, SD: standard deviation, $\mathrm{n}=24$

3. Lateral bowing on radiographs and bone histology

Lateral bowing of the femur was present in 16 legs and absent in 18 legs, according to the method proposed by Fujimaki et al., (Fig. 1) [7]. All 16 cases with lateral bowing of the femur had femoral shaft fractures. Bone biopsy performed in 13 of the 24 patients $(54.2 \%)$ revealed low bone turnover in 9 patients (Fig. 2A) and non-low bone turnover in 4 others (Fig. 2B). Two of these 13 patients had markedly defective bone mineralization indicative of osteomalacia (Fig. 2C). 

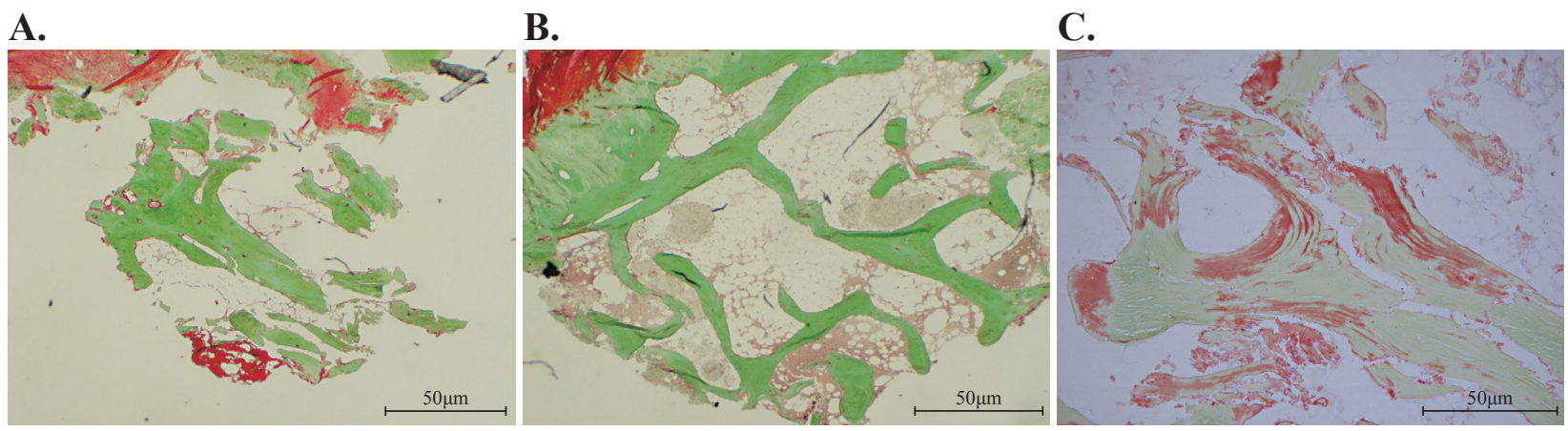

Fig. 2. Bone biopsy results. A. the low bone turnover, B. the non-low bone turn over, C. the form of osteomalacia. $\square$ : Calcified bone, $\square$ : Non-calcified bone (Osteoid).

4. Clinical symptoms, treatment, and time to bone union

Twenty one of the 34 cases with AFF (61.8\%) presented with prodromal symptoms for a mean of 3.9 months (0.25-12 months). Surgical treatment (intramedullary nail fixation) was performed in 31 of the 34 cases $(91.2 \%)$. LIPUS therapy was performed postoperatively in 14 cases $(41.2 \%)$, with a mean duration of 9.7 months (1-20 months). Postoperative teriparatide therapy was performed in 18 cases $(52.9 \%)$, with a mean duration of 8.1 months (2-24 months). The mean time to bone union was 9.0 months (3-24 months; Table 3). The mean time to bone union in cases with complete fracture was 11.5 months (3-24 months), and 3.7 months (3-5 months) in cases with incomplete fracture.

Table 3. Results for clinical symptoms, treatment, and time to bone union

\begin{tabular}{lll}
\hline Characteristic & $\begin{array}{l}\text { Number/ } \\
\text { Average } \pm \text { SD }\end{array}$ & $\begin{array}{l}\text { Ratio/ } \\
\text { (Range) }\end{array}$ \\
\hline $\begin{array}{l}\text { Prodromal symptom (case) } \\
\text { Duration (months) }\end{array}$ & 21 & $61.8 \%$ \\
$\begin{array}{l}\text { Operation (case) } \\
\begin{array}{l}\text { Postoperative LIPUS use } \\
\text { (case) }\end{array}\end{array}$ & 14 & $(0.25-12)$ \\
$\begin{array}{l}\text { Duration (months) } \\
\begin{array}{l}\text { Postoperative teriparatide use } \\
\text { (case) }\end{array}\end{array}$ & 18 & $91.2 \%$ \\
$\begin{array}{l}\text { Duration (months) } \\
\text { Bone healing time (months) }\end{array}$ & $9.0 \pm 6.5$ & $(1-2 \%$ \\
\hline
\end{tabular}

SD: standard deviation, LIPUS: low intensity pulsed ultrasound, $\mathrm{n}=34$

\section{Discussion}

Our multicenter study demonstrated that AFF could be substantially caused by 3 factors: long-term use of $\mathrm{BP}$, drugs other than BP/comorbidity, and femoral lateral bowing. Long-term use of BP is associated with decreased bone remodeling and low bone turnover, thereby increasing bone micro damage accumulation and decreasing bone-healing capacity, with resultant deterioration of bone quality. In the present study, some patients treated with BP for a long time appeared to develop AFF due to the aforementioned mechanism (Fig. 3). Park-Wyllie [8] reported that patients treated with BP for 5 years or more had a 0.76 reduction in the occurrence of proximal femur fracture, but had a 2.74 increase in the risk of subtrochanteric and femoral shaft fractures.

In this study, bone biopsy was performed in 13 cases, using a lump of bone containing cortical/trabecular bone collected from the intramedullary nail insertion site. The results revealed low bone turnover in 9 cases and non-low bone turnover in 4 cases. Therefore, it is difficult to state conclusively that long-term BP use is always associated with low-bone turnover. Thus, deterioration of bone quality finally induces AFF, as shown in Fig. 3.

The obtained values of bone absorption and bone formation markers were all within the normal range. In blood test data, only serum homocysteine was elevated. Saito et al. reported that the serum homocysteine level plays an important role as a marker of poor bone quality, raising the possibility that AFF is involved in the deterioration of bone quality. In addi- 


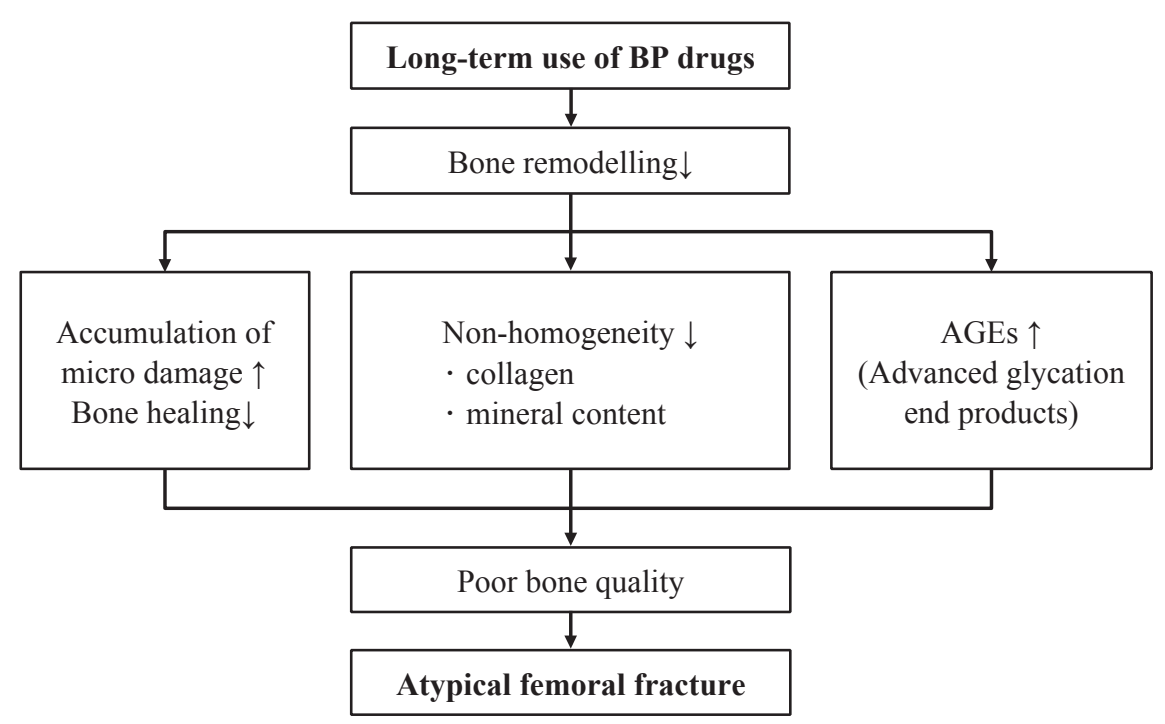

Fig. 3. Consideration of atypical femoral fracture (AFF) pathogenesis with long-term use of BP drugs. BP: bisphosphonate.

tion, bone biopsy in 2 of the present patients showed markedly defective bone mineralization indicative of osteomalacia, as shown in Fig. 1, suggesting the involvement of poor bone quality [9].

Meanwhile, finite element analysis showed that patients with severe lateral bowing of the femur are likely to sustain dynamic stress on the femoral shaft due to axial pressure, as in a case of finite element analysis by trial (Fig. 4). A 79-year-old woman with severe lateral bowing of the femur (lateral bowing ratio $67.0 \%$ ), as shown in Fig. 5A, underwent bilateral total knee arthroplasty (TKA; Fig. 5B). Her leg alignment improved after the surgery, raising her physical activity levels; however, dynamic stress on the femoral shaft increased with time, causing a gradual increase in the lateral bowing of the femur (lateral bowing ratio $70.4 \%$ ), and leading to AFF at 7 years after TKA (Fig. 5C). There have also been reports showing that some drugs (e.g., steroids, TZD, and PPIs) and comorbidities (e.g., SLE, RA, DM or CKD) are associated with the occurrence of insufficiency fractures [10-12]. These factors are also considered to be involved in the development of AFF.

Taken together, the AFF cases presented here can be categorized into the following types: "BP-related type," wherein an association between AFF and BP

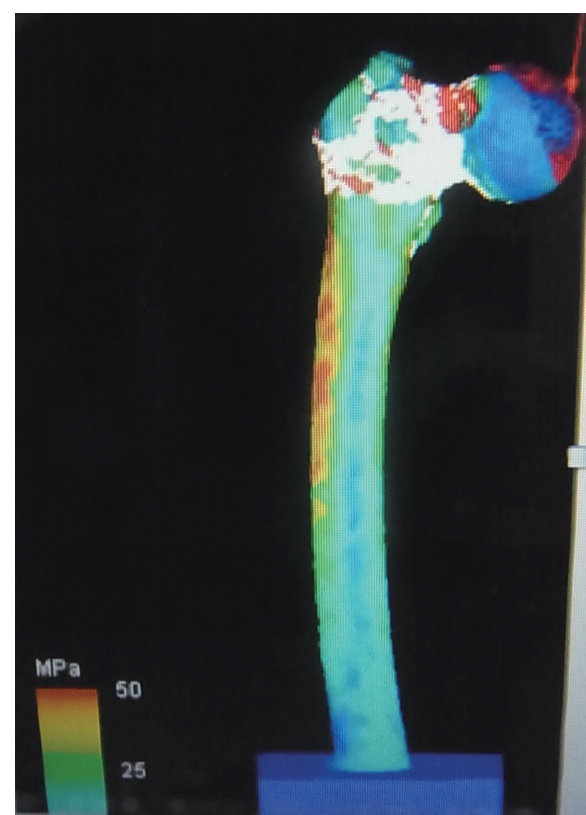

Fig. 4. A case of lateral bowing deformity of femur with mechanical stress, which was analyzed by the finite element method.

therapy for 5 years or more cannot be denied; "drug/ comorbidity type," wherein an association of AFF with drugs such as steroids, PPIs, and TZD, or with comorbidities such as RA, SLE, and CKD, cannot be 
A.

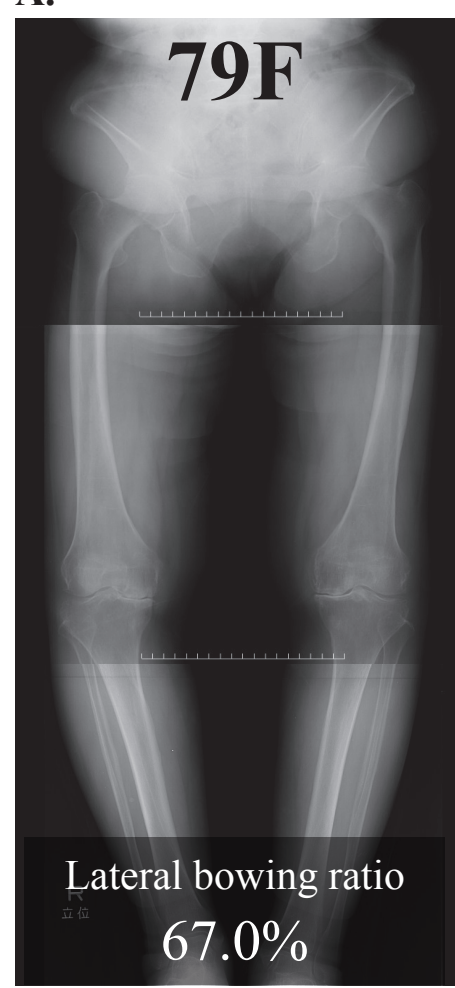

B.

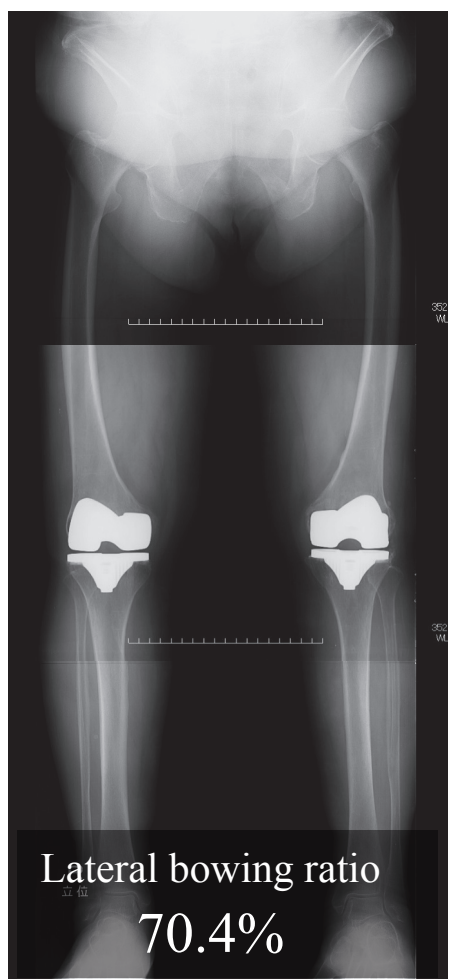

C.

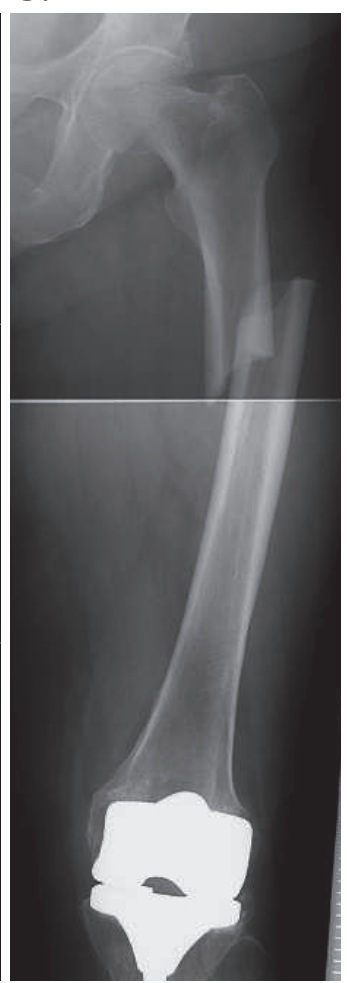

Fig. 5. Lower-limb radiographs in a 79-year-old woman with severe lateral bowing of the femur. Increased ratio of lateral bowing deformity of the femur associated with lower limb alignment changes before (A) and after (B) TKA surgery, C. Atypical femoral fracture at 7 years after the TKA surgery. TKA: total knee arthroplasty.

ruled out; "lateral bowing type," wherein lateral bowing of the femur is noted; and "mixed type," wherein the above 3 types are mutually correlated. In the present 24 patients, 2 were classified as BP-related type, 3 as drug/comorbidity type, 2 as lateral bowing type, and 17 (accounting for the majority of the patients) as mixed type. The mixed types included: BP-related + lateral bowing type $(n=4)$, BP-related + drug/comorbidity type ( $n=7)$, drug/comorbidity + lateral bowing type $(n=3)$, and BP-related + drug/comorbidity + lateral bowing type ( $n=3$; Fig. 6$)$. These observations suggest that the etiology of AFF cannot be explained by a single cause. Thus, a multifactorial etiology, including poor bone quality due to mutual interactions and mechanical stress, appears to be responsible for the occurrence of AFF. More specifically, in addition to poor bone quality (deterioration of bone material properties) associated with the degradation of collagen due to increased advanced glycation end-product cross-linking associated with long-term BP use, lateral bowing of the femur associated with degradation of

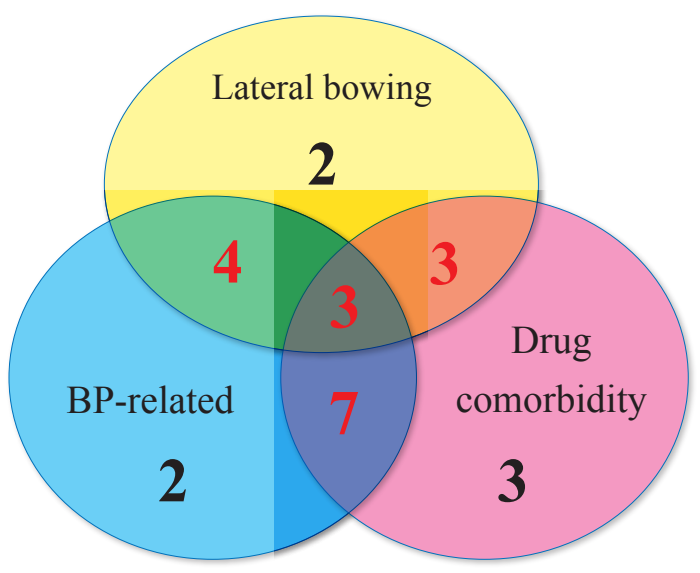

Fig. 6. Classification of the developmental factors of all AFF cases.

bone structural properties may be involved in the occurrence of AFF [8].

However, this study has the limitations of not being randomized or prospective. 


\section{Conclusions}

1. The etiology of AFF was categorized based on the data of AFF cases compiled in a multicenter study.

2. Multifactorial involvement in the occurrence of AFF was seen in the majority of the cases with AFF.

\section{Acknowledgements}

We greatly thank the following doctors for providing data on their patients for this multicenter study: Dr. Yuzo Tanaka, Ryusoh Orthopedic Hospital; Dr. Shoji Tsuji, Department of Orthopedic Surgery, Kitakyushu City Yahata Hospital; Dr. Yoshifumi Fuse, Department of Orthopaedic Surgery, Saka Midorii Hospital; and Dr. Takafumi Tajima, Nippon Kokan Fukuyama Hospital, Shinichiro Takada, and Kayoko Furukawa, and our university hospital. Moreover, the authors would like to thank Mr. C.P.Carman for the English language review.

\section{Conflicts of Interest}

There are no current external funding sources for this study, and no conflicts of interest to declare.

\section{References}

1. Odvina CV, Zerwekh JE, Rao DS, MaaloufN, Gottschalk FA \& Pak CY (2005): Severely suppressed bone turnover: a potential complication of alendronate therapy. J Clin Endocrinol Metab 90: 1294-1301

2. Wakabayashi Y, Kurosa Y, Ishizuki M \& Okawa A (2014): Stress fracture of the bowed femoral shaft is another cause of atypical femoral fracture in elderly Japanese: a case series. J Orthop Sci 19: 579-586

3. Chen LP, Chang TK, Huang TY, Kwok TG \& Lu YC (2014): The correlation between lateral bowing angle of the femur and the location of atypical femur fractures. Calcif Tissue Int. 95: 240-247
4. Oh Y, Wakabayashi Y, Kurosa Y, Fujita K \& Okawa A (2014): Potential pathogenic mechanism for stress fractures of the bowed femoral shaft in the elderly: Mechanical analysis by the CT-based finite element method. Injury 45: 1764-1771

5. Shane E, Burr D, Ebeling PR, et al (2010): Atypical subtrochanteric and diaphyseal femoral fractures: report of a task force of the American society for bone and mineral research. J Bone Miner Res 25: 2267-2294

6. Shane E, Burr D, Abrahamsen B, et al. (2014): Atypical subtrochanteric and diaphyseal femoral fractures: second report of a task force of the American Society for Bone and Mineral Reserch. J Bone Miner Res 29: 1-23

7. Fujimaki Y, Kanekasu K, Honjyo S \& Nakata O (2002): The radiological examination for the lateral bowing deformity of femur (in Japanese). Kansetsugeka. 21: 1144-1151

8. Park-Wyllie LY, Mamdani MM, Juurlink DN, Hawker GA, Gunraj N, Austin PC, Whelan DB, Weiler PJ \& Laupacis A (2011): Bisphosphonate use and the risk of subtrochanteric or femoral shaft fractures in older women. JAMA 305: 783-789

9. Saito M \& Marumo K (2012): The possibility of application of a new approach bone marker of a new approach for osteoporosis, bone fractures, bone strength evaluation of osteoporosis. (in Japanese) J Jpn Orthop Assoc 86: 210-218

10. Liu WC, Yen JF, Lang CL, Yan MT \& Lu KC (2013): Bisphophonates in CKD patients with low bone mineral density. Scientific World J 2013: 837573

11. Fraser LA, Leslie WD, Targownik LE, Papaioannou A, Adachi JD, CaMos Reserch Group (2013): The effect of proton pump inhibitors on fracture risk: report from the Canadian multicenter osteoporosis study. Osteoporos Int 24:1161-1168

12. Lima GA, Paranhos Neto Fde P, Pereira GR, Gomes CP \& Farias ML (2014): Osteoporosis management in patient with renal function impairment. Arq Bras Endocrinol Metabol 58: 530-539 
多施設共同研究による非定型大腿骨骨折の検討

善家 雄吉 ${ }^{1}$, 池田 聡 ${ }^{2}$, 福田 文雄 $^{3}$, 田中 正宏 ${ }^{4}$, 田中 秀敏 ${ }^{2}$, 平野 文崇 ${ }^{5}$, 酒井 昭典 ${ }^{6}$

1 産業医科大学病院 整形外科

2 健愛記念病院 整形外科

${ }^{3}$ 北九州総合病院 整形外科

4 マツダ病院 整形外科

5 九州労災病院 門司メディカルセンター 整形外科

6 産業医科大学 医学部 整形外科学

要旨：非定型大腿骨骨折 (atypical femoral fracture : AFF) は, ビスフォスフォネート (BP) 製剤の長期使用, ある いは日本人高齢者に扔ける外弯した大腿骨に扔けるストレス骨折など幾つかの要因が関与している，しかしなが ら, 各施設単独では, まとまった症例数を経験することができないため, 当院および関連施設に扔いて過去に発生し た AFF 症例を多施設共同研究として集積した。本研究の目的は, そのデー夕を解析し, 特徵を分類化することであ る. 対象は, 多施設で発生したAFF24症例 34 骨折 (両側 8 例), 男性 1 例, 女性 23 例で, 平均年齢 73.0 歳である. 評価 項目は, ビスフォスフォネート (BP) 製剂使用の有無と使用期間, その他薬剂使用歴, 合併症の有無, 骨折部位, 大腿 骨外弯の有無, 骨生検パラメー夕, 骨癒合期間などとした。結果は, BP 製剤使用例は 19 例, 投与期間は平均 6.1 年で あった。骨折部位は, 転子下 16, 骨幹部 18 であり, 完全骨折 22 , 不全骨折 12 であった。また大腿骨外弯ありは 16 例 で,すべて骨幹部に発生していた。骨癒合期間は平均 9.0 个月であり, 完全骨折が平均 11.3 个月であったのに対し, 不 全骨折は平均 3.7 个月であった. 全症例を BP 関連型 $: 2$ 例, 薬剂·合併症型 $: 3$ 例, 外弯型 $: 2$ 例, 混合型 $: 17$ 例に分類し た．本骨折の成因は単一のみでは説明し難く, 相互作用による骨質の劣化や, 機械的ストレスが絡んだ多因子関与で あった。

キーワード : 非定型大腿骨骨折, 多施設共同研究, ビスフォスフォネート, 大腿骨外弯, 多因子関与. 